\title{
PENGARUH PENERAPAN BAHAN AJAR MODEL INKUIRI TERBIMBING TERINTEGRASI KEARIFAN LOKAL BERBASIS OUTCOME BASED EDUCATION (OBE) MELALUI PENGGUNAAN MEDIA ONLINE TERHADAP LITERASI SAINS
}

\section{THE EFFECT OF IMPLEMENTATION OF TEACHING MATERIALS GUIDED INQUIRY MODEL OF INTEGRATED LOCAL WISDOM BASED OUTCOME BASED EDUCATION (OBE) TROUGH THE USE OF ONLINE MEDIA ON SCIENTIFICT LITERACY}

\author{
Juliani Rohaili*, Dadi Setiadi dan Kusmiyati \\ Program Studi Pendidikan BiologiFKIP, Universitas Mataram, Mataram, Indonesia \\ *E-mail: julianirohaili27@gmail.com
}

Diterima: 12 Januari 2021. Disetujui: 11 Februari 2021. Dipublikasikan: 3 Maret 2021

\begin{abstract}
Abstrak: Penelitian ini bertujuan untuk mengetahui pengaruh penerapan bahan ajar model inkuiri terbimbing terintegrasi kearifan lokal berbasis outcome based education (OBE) melalui penggunaan media online terhadap literasi sains peserta didik kelas X di SMAN 8 Mataram. Jenis penelitian ini adalah eksperimen semu (Quasi Experiment), dengan desain penelitian non-equivalent control group design. Populasi penelitian seluruh peserta didik kelas X MIA (164 orang). Teknik pengambilan sampel menggunakan purposive sampling. Instrumen penelitian menggunakan angket validasi ahli, angket respon peserta didik, dan tes literasi sains. Hasil validasi kelayakan bahan ajar oleh ahli menunjukkan skor rata-rata 0,78 yang termasuk dalam kategori layak. Presentase respon peserta didik terhadap bahan ajar yaitu 55,93\% yang tergolong sangat menarik. Data keterbacaan menggunakan flesh kinchaid grade level menyatakan naskah bahan ajar layak untuk kelas $\mathrm{X}$ dengan rentang usia pengguna 13-16 tahun dan rata-rata indeks keterbacaan sebesar 10,7. Hasil uji hipotesis MANOVA menunjukkan nilai signifikansi literasi sains peserta didik yaitu $0,000(p<0,05)$, sehingga penerapan bahan ajar model inkuiri terbimbing terintegrasi kearifan lokal berbasis outcome based education melalui penggunaan media online berpengaruh terhadap literasi sains peserta didik. Kesimpulan dari penelitian ini menunjukkan bahwa penerapan bahan ajar model inkuiri terbimbing terintegrasi kearifan lokal berbasis outcome based education melalui penggunaan media online berpengaruh terhadap literasi sains peserta didik.
\end{abstract}

Kata Kunci: Bahan Ajar, Inkuiri Terbimbing, Literasi Sains.

\begin{abstract}
The purpose of this research of applying teaching materials models guided inquiry integrated with local wisdom based on outcome based education (OBE) through the use of online media on scientifict literacy of the $10^{\text {th }}$ grade students in high school 8 Mataram. The type of this research was Quasi Experimental, with a nonequivalent control group design research design. The population of the study was all students of class X MIA (164 stundent). The sample collection technique used was purposive sampling. The research instrument used expert validation questionnaires, student response questionnaires, and tests of scientifict literacy. The results of the validation of the feasibility of teaching materials by experts show an average score of 0.78 which is included in the feasible category. The percentage of students responses to teaching materials was 55.93\% which was classified as very interesting. Readability data using the flesh kinchaid grade level states the teaching material text is feasible for $10^{\text {th }}$ grade students with a user age range of 13-16 years old and an average readability index of 10.7. The results of the MANOVA hypothesis test showed that the significance value of scientifict literacy of students was $0,000(\mathrm{p}<0.05)$, meaning that $\mathrm{H}_{0}$ was rejected, so the application of guided inquiry model teaching materials integrated local wisdom based on outcome based education through the use of online media had an effect on scientifict literacy of student. The conclusion of this study shows that the application of guided inquiry model teaching materials integrated local wisdom based on outcome based education through the use of online media has an effect on the scientifict literacy of $10^{\text {th }}$ grade students in high school 8 Mataram.
\end{abstract}

Keywords: Teaching Materials, Guided Inquiry, Scientifict Literacy.

\section{PENDAHULUAN}

Wabah Coronavirus Diseases (Covid-19) menjadi persoalan multidimensi yang dihadapi dunia, hal tersebut juga dirasakan dampaknya dalam dunia pendidikan yang mengharuskan kegiatan pembelajaran harus tetap berjalan meskipun peserta didik berada dirumah. Hal ini sesuai dengan keputusan Menteri Pendidikan dan Kebudayaan Republik Indonesia terkait Surat Edaran Nomor 4
Tahun 2020 tentang Pelaksanaan Kebijakan Pendidikan dalam Masa Darurat Penyebaran Covid19.

Kondisi demikian menuntut lembaga pendidikan untuk melakukan inovasi dalam proses pembelajaran. Salah satu bentuk inovasi tersebut ialah dengan melakukan pembelajaran secara online atau daring (dalam jaringan). Pembelajaran daring merupakan sebuah inovasi pendidikan yang 
melibatkan unsur teknologi informasi dalam pembelajaran. Pembelajaran daring merupakan sistem pendidikan jarak jauh dengan sekumpulan metode pengajaran dimana terdapat aktivitas pengajaran yang dilaksanakan secara terpisah dari aktivitas belajar [8].

Pembelajaran online tentunya akan kurang bermakna tanpa sinergitas strategi dan metode pembelajaran yang tepat. Salah satu penerapan yang dapat memadukan pembelajaran online adalah pembelajaran yang tidak hanya menekankan pada penguasaan produk saja, tetapi juga mampu berkembang menjadi anggota masyarakat yang melek sains (science literacy) yang baik. Secara sederhana literasi sains diartikan sebagai kemampuan menggunakan pengetahuan sains, mengidentifikasi pertanyaan, dan menarik kesimpulan berdasarkan bukti-bukti, dalam rangka memahami serta membuat keputusan terhadap suatu masalah.

Hasil survey tingkat literasi sains peserta didik menengah yang dilakukan OECD tahun 2015 menunjukkan hasil bahwa tingkat literasi peserta didik di Indonesia masih pada tingkat yang rendah, walaupun poinnya meningkat dari survey yang dilakukan pada tahun 2012. Indonesia berada pada peringkat ke 61 dari 72 negara peserta. Rata-rata skor literasi sains peserta didik di Indonesia adalah sebesar 403 poin, padahal standar rata-rata skor dari OECD sebesar 501 poin. Hasil survey PISA 2015 juga menunjukkan bahwa level literasi sains peserta didik di Indonesia berada pada level 1, dan nyaris mencapai literasi sains level 2. Hal ini berarti bahwa peserta didik Indonesia memiliki kemampuan memilih penjelasan ilmiah yang paling baik untuk data yang diberikan dalam konteks pribadi yang familiar, lokal, dan global [10].

Rendahnya literasi sains peserta didik disebabkan oleh beberapa faktor diantaranya pembelajaran masih didominasi oleh guru (teacher center), pemilihan model dan metode pembelajaran yang digunakan masih bersifat monoton, fasilitas pembelajaran terbatas, minat dan motivasi rendah, dan bahan ajar yang digunakan oleh guru belum memenuhi pembelajaran abad 21. Salah satu faktor yang harus diperhatikan untuk meningkatkan keterampilan proses dan literasi sains peserta didik ditengah pandemi Covid-19 adalah bahan ajar yang sesuai dengan pembelajaran abad 21, yaitu pembelajaran yang di dalamnya memuat aspek keterampilan proses dan literasi sains dan materi yang sesuai dengan tagiahan kompetensi dan analisis kebutuhan peserta didik.

Proses pembelajaran biologi menekankan pada pemberian pengalaman langsung untuk mengembangkan kompetensi agar menjelajahi dan memahami alam sekitar secara ilmiah. Pembelajaran biologi diharapkan mampu menumbuhkan karakter peserta didik yang lebih menghargai berbagai budaya yang ada dan berusaha untuk melestarikannya. Menurut [4] pendidikan sains dapat dikembangkan dengan bertumpu pada keunikan dan keunggulan suatu daerah, termasuk budaya lokal. Aspek budaya lokal dalam pembelajaran dapat meningkatkan efektivitas proses pembelajaran [14].

Tolak ukur keberhasilan proses pembelajaran dapat dilihat dari capaian hasil dan proses pembelajaran. Outcome Based Education (OBE) atau disebut dengan pendidikan berbasis hasil adalah pendidikan yang berpusat pada peserta didik, berorientasi pada hasil untuk pendidikan dan pelatihan yang dibangun di atas gagasan bahwa semua peserta didik perlu dan dapat mencapai potensi penuh mereka meskipun tidak secara bersamaan [6]. Hasil positif dari pendekatan sistem pembelajaran beorientasi luaran (OBE) ditandai dengan terpenuhinya capaian pembelajaran yang ditentukan dimata pelajaran. Penerapan OBE belum banyak diimplementasikan di sekolah. Oleh karena itu OBE diharapkan dapat membantu menghasilkan peserta didik yang kreatif, interaktif dan inovatif.

Uraian tersebut menginspirasi penulis untuk melakukan penelitian yang dirumuskan dalam judul "Pengaruh Penerapan Bahan Ajar Model Inkuiri Terbimbing Terintegrasi Kearifan Lokal Berbasisi Outcome Based Education (OBE) melalui penggunaan media online Terhadap Keterampilan Proses Sains Peserta Didik Kelas X di SMAN 8 Mataram".

Penelitian ini bertujuan untuk mengetahui apakah penggunaan bahan ajar model inkuiri terbimbing terintegrasi kearifan lokal berbasis OBE melalui penggunaan media online berpengaruh terhadap literasi sains peserta didik kelas X di SMAN 8 Mataram.

\section{METODE PENELITIAN}

Jenis penelitian yang digunakan dalam penelitian ini adalah eksperimen semu (Quasi Experiment). Desain penelitian yang digunakan adalah Non-Equivalent Control Group Design. Penelitian dilaksanakan di SMAN 8 Mataram pada semester genap tahun ajaran 2019/2020. Populasi dalam penelitian ini seluruh peserta didik kelas $\mathrm{X}$ jurusan MIA (Matematika dan Ilmu Pengetahuan Alam) yang terdiri dari 5 kelas dengan total keseluruhan adalah 164 peserta didik. Pengambilan sampel menggunakan purposive sampling, kelas $\mathrm{X}$ MIA 4 sebagai kelas kontol dan kelas X MIA 5 sebagai kelas eksperimen. Teknik pelaksanaan penelitian menggunakan aplikasi WhatsApp, Youtube, dan Google Form, pelaksanaan pembelajaran terdapat pada video pembelajaran sesuai dengan sintaks inkuiri terbimbing. Pengumpulan data dilakukan dengan menggunakan angket dan tes. Analisis data dilakukan dengan uji MANOVA dengan menggunakan SPSS 17.0.

\section{HASIL DAN PEMBAHASAN \\ Data Hasil Uji Kelayakan Bahan Ajar}

Validasi bahan ajar dilakukan oleh 3 orang ahli yang terdiri dari 2 orang dosen ahli yaitu Dr. 
Dadi Setiadi, M.Sc. sebagai ahli materi dan Dra. Hj. Kusmiyati, M.Si. sebagai ahli media. Seorang ahli lainnya adalah guru Biologi di SMAN 8 Mataram yaitu Ibu Dra. Suharti. Data validasi isi terdiri dari tiga aspek penilaian, yaitu terdiri dari aspek kelayakan isi, kelayakan penyajian, dan kelayakan bahasa. Data validitas isi menurut ahli pada tiga aspek tersebut terangkum pada Tabel 1 .

Tabel 1 menunjukkan bahwa ketiga aspek memiliki Aiken skor pada kategori layak menurut [11] berdasarkan kategori kelayakan Aiken skor. Penilaian aspek isi terdiri dari butir pertanyaan meliputi materi ajar. Kemudian, aspek penyajian terdiri dari penilaian layout dan grafis bahan ajar. Sedangkan pada aspek kebahasaan peilaian terdiri dari penilaian terhadap susunan kata, istilah, dan simbol pada bahan ajar.

Data keterbacaan bahan ajar didapatkan menggunakan readability terdiri dua bagian yang ada pada bahan ajar yang disusun. Kedua bagian tersebut meliputi materi komponen ekosistem dan satuansatuan makhluk hidup penyusun ekosistem dan polapola interaksi dalam ekosistem. Hasil analisis keterbacaan bahan ajar menggunakan Flesh Kincaid Grade Level terangkum dalam Table 2.

Tabel 1. Hasil Aiken's V

\begin{tabular}{lccccc}
\hline \multirow{2}{*}{ Aspek } & \multicolumn{3}{c}{ Validator } & \multirow{2}{*}{ Rerata } & $\begin{array}{c}\text { Aiken } \\
\text { Skor }\end{array}$ \\
\cline { 2 - 4 } & $\mathbf{1}$ & $\mathbf{2}$ & $\mathbf{3}$ & & 0.79 \\
\hline Isi & 3.41 & 3.00 & 3.71 & 3.37 & 0.78 \\
Penyajian & 3.17 & 3.00 & 3.83 & 3.33 & 0.78 \\
Kebahasaan & 3.44 & 3.00 & 3.57 & 3.33 & \\
\hline
\end{tabular}

Tabel 2. Indeks Flesh Kincaid Grade Level

\begin{tabular}{lccc}
\hline \multicolumn{1}{c}{ Materi } & Indeks & $\begin{array}{c}\text { Tingkat } \\
\text { Kelas }\end{array}$ & $\begin{array}{c}\text { Rentang } \\
\text { Usia }\end{array}$ \\
\hline $\begin{array}{l}\text { Komponen ekosistem dan satuan-satuan } \\
\text { makhluk hidup penyusun ekosistem }\end{array}$ & 10.4 & Kelas 10 & $13-16$ tahun \\
\hline Pola-pola interaksi dalam ekosistem & 10.9 & Kelas 10 & 13-16 tahun \\
\hline
\end{tabular}

Tabel 3. Data Hasil Respon Peserta Didik

\begin{tabular}{lcccc}
\hline \multicolumn{5}{c}{ Presentase Peserta Didik (\%) } \\
\hline \multicolumn{1}{c}{ Aspek } & Kurang & Cukup & Menarik & Sangat Menarik \\
\hline Penyajian & 0 & 4.60 & 41.38 & 52.87 \\
\hline Bahasa & 0 & 4.31 & 37.07 & 58.62 \\
\hline Isi & 0 & 6.90 & 36.21 & 56.32 \\
\hline Total $(\%)$ & 0 & 5.27 & 38.22 & 55.94 \\
\hline
\end{tabular}

Tabel 4. Hasil Test Between-Subject Effect

\begin{tabular}{lllllll}
\hline Source & DV & $\begin{array}{c}\text { Type III Sum of } \\
\text { Squares }\end{array}$ & df & $\begin{array}{l}\text { Mean } \\
\text { Square }\end{array}$ & F & Sig. \\
\hline Corrected Model & KPS & $3019.991^{\mathrm{a}}$ & 1 & 3019.991 & 39.483 & .000 \\
\hline Intercept & KPS & 311754.417 & 1 & 311754.417 & 4075.857 & .000 \\
\hline Kelas & KPS & 3019.991 & 1 & 3019.991 & 39.483 & .000 \\
\hline Error & KPS & 4512.796 & 59 & 76.488 & & \\
\hline Total & KPS & 317025.000 & 61 & & & \\
\hline Corrected Total & KPS & 7532.787 & 60 & & & \\
\hline Keterangan:
\end{tabular}

Keterangan: $*$ DV $=$ Dependent Variabel

*KPS = Keterampilan Proses Sains

Tabel 2 menunjukkan bahwa materi pertama komponen ekosistem dan satuan-satuan makhluk hidup penyusun ekosistem memperoleh nilai Flesh Kincaid Grade Level sebesar 10.4 yang masuk kategori layak untuk peserta didik kelas 10. Begitu juga dengan materi kedua yakni pola-pola interaksi dalam ekosistem masuk pada kategori layak untuk siswa kelas 10 dengan nilai 10.9. Rentang usia yang 
layak mengguakan naskah bahan ajar yang disusun mulai dari peserta didik berusia 13 sampai 16 tahun. Kelayakan keterbacaan bahan ajar ini diperoleh berdasarkan kategori indeks Flesh Kincaid Grade Level.

Data respon peserta didik terhadap bahan ajar model inkuiri terbimbing terintegrasi kearifan lokal berbasis OBE melalui penggunaan media online yang disusun oleh peneliti menunjukkan bahwa masuk dalam kategori sangat menarik. Data hasil angket respon peserta didik terangkum dalam Tabel 3 .

Tabel 4 di atas menunjukkan bahwa secara keseluruhan bahan ajar model inkuiri terbimbing terintegrasi kearifan lokal berbasis OBE melalui penggunaan media online dari sudut pandang pengguna dinyatakan sangat menarik digunakan dengan presentase sebesar $55.94 \%$, sedangkan untuk kategori menarik, cukup dan kurang secara berturutturut sebesar $38.22 \%, 5.27 \%$, dan $0 \%$.

\section{Data Pre-test dan Post-test Literasi Sains}

Hasil analisis literasi sains menunjukkan ratarata nilai pretest dan posttes literasi sains dapat dilihat pada Gambar 1.

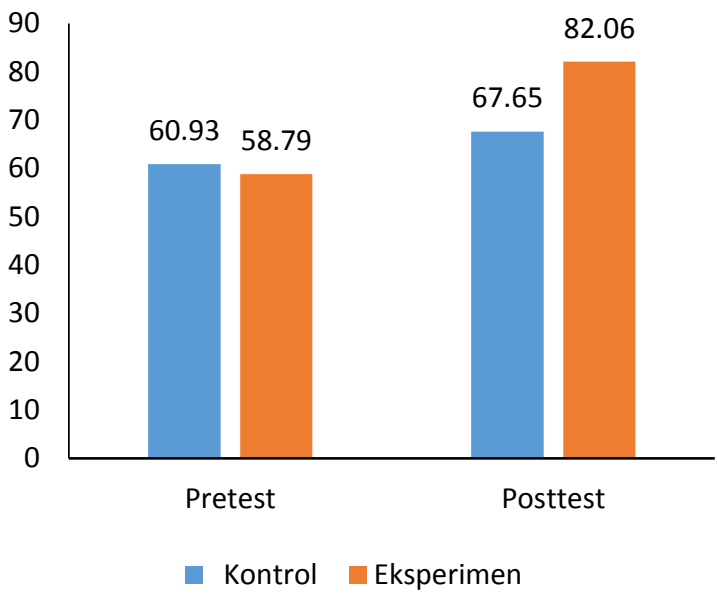

Berdasarkan gambar di atas menunjukkan bahwa nilai rata-rata pretest pada kelompok kontrol adalah 60.93 sedangkan rata-rata nilai pretest pada kelompok eksperimen adalah 58.79. Hasil rata-rata post-test pada kelompok kontrol menunjukkan nilai rata-rata 67.65 sedangkan kelompok kontrol menunjukkan nilai rata-rata 82.06.

\section{Data Hasil Uji Hipotesis}

Uji hipotesis yeng digunakan adalah uji MANOVA. Berdasarkan hasil analisis Test BetweenSubject Effect yang menunjukan adanya pengaruh variabel secara individu, untuk mengetahui pengaruh variabel bebas dan kovariat terhadap masing-masing variabel tergantung. Hasil uji output Test BetweenSubject Effect ditunjukan pada tabel 4.

Berdasarkan tabel 4 khususnya pada sumber variasi (source) baris kelas terlihat bahwa nilai signifikansi untuk literasi sains diperoleh sebesar
0.000, berdasarkan nilai $p$-value (Sig) yang diperoleh nilai kemampuan literasi sains menunjukkan nilai $0.000<0.05$. Maka Ho ditolak, yang artinya bahwa terdapat pengaruh penerapan bahan ajar model inkuiri terbimbing terintegrasi kearifan lokal berbasis OBE melalui media online terhadap literasi sains peserta didik kelas $\mathrm{X}$ di SMAN 8 Mataram tahun ajaran 2019/2020. Oleh karena itu, bahan ajar model inkuiri terbimbing terintegrasi kearifan lokal berbasis OBE melalui penggunaan media online dapat diterapkan dalam proses pembelajaran karena berpengaruh terhadap peningkatan literasi sains peserta didik dengan memfasilitasi peserta didik tahap-tahap pembelajaran yang menjadi dasar pencapaian aspek kompetensi literasi sains yang terdiri dari menjelaskan fenomena secara ilmiah, mengevaluasi dan mendesain penyelidikan ilmiah, dan interpretasi dan membuktikan data secara ilmiah. Menurut [12] langkah pembelajaran orientasi dapat mengembangkan literasi sains aspek menjelaskan fenomena ilmiah, langkah menganalisis data dapat mengembangkan literasi sains indikator menginterpretasikan bukti dan data ilmiah, dan langkah pembelajaran menyusun kesimpulan dapat mengembangkan literasi sains indikator merancang dan mengevaluasi penyelidikan ilmiah.

Indikator literasi sains menjelaskan fenomena secara ilmiah, ialah kemampuan yang menuntut peserta didik selalu mengembangkan rasa ingin tahu menjawab segala pertanyaan yang diberikan dengan proyek yang telah dilaksanakan. Dalam hal ini peserta didik diharapkan mampu mengaplikasikan pengetahuan yang dimilikinya dalam situasi yang diberikan untuk menjelaskan atau mendeskripsikan fenomena dan mendeskripsikan perubahan, mengidentifikasi deskripsi, eksplanasi dan prediksi yang sesuai. Kompetensi menjelaskan fenomena secara ilmiah dibutuhkan peserta didik untuk mengingat kembali konten pengetahuan yang tepat pada keadaan yang diberikan dan menggunakannya untuk menginterpretasi dan menyediakan penjelasan kepada fenomena yang menarik. Implementasi indikator menjelaskan fenomena secara ilmiah pada bahan ajar model inkuiri terbimbing terintegrasi kearifan lokal berbasis OBE melalui penggunaan media online terdapat pada kolom mari berfikir kritis dan pada panduan aktivitas inkuiri terbimbing peserta didik, karena peserta didik dilatih untuk berhadapan dengan masalah, mengumpulkan data pengujian, dan pengumpulan data dalam kegiatan pengamatan. Panduan aktivitas inkuiri terbimbing peserta didik dalam bahan ajar model inkuiri terbimbing terintegrasi kearifan lokal berbasis OBE melalui penggunaan media online melatih peserta didik untuk merumuskan masalah secara individu maupun kelompok dan menentukan cara penyelesaian masalah, proses tersebut akan menuntut peserta didik untuk mengelolah pengetahuan yang dimilikinya dalam menyelesaikan masalahnya berdasarkan keadaan yang diberikan oleh pendidik, setelah itu 
peserta didik melakukan pengumpulan data dalam kegiatan pengujian, dengan kegiatan melakukan identifikasi terhadap kejadian atau fenomena dalam kehidupan sehari-hari.

Indikator literasi sains mengevaluasi dan mendesain penyelidikan ilmiah merupakan kemampuan melakukan kegiatan mendeskripsikan dan menilai penyelidikan ilmiah dan dapat menjawab pertanyaan secara ilmiah. Menurut [9] kompetensi mengevaluasi dan mendesain penyelidikan ilmiah dibutuhkan untuk mengevaluasi laporan dari penemuan dan investigasi secara kritis. Indikator ini menuntut peserta didik membuat kesimpulan dan menafsirkan bukti ilmiah. Pada panduan aktivitas inkuiri terbimbing peserta didik dalam bahan ajar model inkuiri terbimbing terintegrasi kearifan lokal berbasis $\mathrm{OBE}$ melalui penggunaan media online melatih peserta didik untuk melakukan kegiatan menyusun kesimpulan dari hasil pengamatan yang dilakukan. Peserta didik melakukan pengumpulan data atau literatur yang merujuk pada topik pembelajaran, setelah itu peserta didik secara berkelompok akan melakukan pengakajian dan pengamatan yang dilakukan untuk menguji rumusan masalah dan hipotesis yang telah disusun sebelumnya dengan merancang pengamatan sesuai dengan lembar kerja yang telah disediakan. Setelah itu, peserta didik akan menjawab pertanyaan dan menyusun kesimpulan berdasarkan data yang telah dikumpulkan melalui kegiatan pengamatan sebelumnya. Hal ini sesuai dengan pernyataan [13] yang menyatakan bahwa langkah pembelajaran menyusun kesimpulan dapat mengembangkan kompetensi indikator mengevaluasi dan merancang penyelidikan ilmiah. Melalui kegiatan pengamatan peserta didik dapat melakukan kegiatan-kegiatan yang berorientasi pada kegiatan mengamati, mencatat hasil pengamatan, pengumpulan data, dan menarik kesimpulan, sehingga peserta didik akan menemukan sendiri konsep-konsep yang harus dipahaminya.

Indikator literasi sains interpretasi data dan membuktikan data secara ilmiah merupakan kemampuan individu untuk melakukan analisis dan mengevaluasi data, memberi tanggapan dan argumen untuk mencapai kesimpulan dengan tepat. Oleh karena itu, peserta didik dituntut untuk memiliki kemampuan dalam menafsirkan bukti ilmiah atau data yang diperoleh melalui kegiatan pengamatan ataupun berdasarkan teori/literatur yang dipergunakan untuk menarik kesimpulan dan memberikan alasan yang tepat mengapa alasan tersebut dapat diterima maupun ditolak. Panduan aktivitas inkuiri terbimbing dalam bahan ajar model inkuiri terbimbing terintegrasi kearifan lokal berbasis OBE melalui penggunaan media online peserta didik dilatih untuk melakukan analisis terhadap hasil pengamatan bersama kelompok ataupun secara individu untuk membuat kesimpulan sesuai dengan rumusan masalah yang telah disusun sebelumnya, setelah itu secara berkelompok menganalisis data bersama kelompok yang diperkuat dengan data dan teori yang mendukung hasil pengamatan dan mengaitkan kesimpulan dengan rumusan yang telah dibuatnya.

Berdasarkan indikator-indikator tersebut maka bahan ajar model inkuiri terbimbing terintegrasi kearifan lokal berbasis OBE melalui penggunaan media online mampu mendukung pengingkatan kemampuan literasi sains peserta didik, karena memiliki langkah-langkah yang menjadi dasar pencapaian tiga kompetensi literasi sains. Aktivitas inkuiri terbimbing dapat mengembangkan pemahaman, mendorong berfikir kritis dan analitis. Kemampuan berfikir kritis dan analitis menjadi dasar untuk menjawab kompetensi literasi sains, sehingga pembelajaran inkuiri tembimbing dapat meningkatkan kompetensi ilmiah peserta didik [15].

Keterkaitan bahan ajar model inkuiri terbimbing terintegrasi kearifan local berbasis $\mathrm{OBE}$ dengan peningkatan literasi sains saling berhubungan satu sama lain. Hal ini berdasarkan fakta bahwa kegiatan inkuiri dianggap dapat meningkatkan literasi sains karena mampu melatih peserta didik untuk melakukan sains itu sendiri, baik dalam pembelajaran menggunakan bahan ajar berbasis inkuiri di dalam kelas maupun penerapan sains dalam kehidupan sehari-hari [2]. Kurangnya kegiatan peserta didik untuk meningkatkan literasi sains dan inkuiri pada kegiatan pembelajaran IPA dikhawatirkan akan membuat kualitas pembelajaran menjadi menurun. Hal ini sesuai dengan [3] yang mengemukakan bahwa masalah kemelekan sains (scince literacy) dan kemelekan inkuiri (iquiry literacy) akan berdampak pada perkembangan keterampilan peserta didik sebagai bagian dari komponen-komponen kecakapan hidup.

Bahan ajar model inkuiri terbimbing terintegrasi kearifan lokal berbasis OBE perlu untuk diterapkan dalam proses pembelajaran dengan tujuan aktivitas inkuiri terbimbing dalam bahan ajar yang digunakan peserta didik dapat mengarahkan, menggiring peserta didik berusaha melakukan kegiatan yang dapat meningkatkan tingkat literasi sainsnya. Keuntungan peserta didik yang dapat meningkatkan literasi sainsnya adalah memiliki kemampuan dalam memahami lingkungan hidup dan masalah-masalah lain yang dihadapi, selain itu konsep biologi yang bersifat konkret dan didukung dengan adanya integrasi budaya lokal dalam pembelajaran sains akan dapat mempermudah peserta didik dalam mencari informasi semaksimal mungkin tentang materi pelajaran yang akan dipelajari karena kedekatan peserta didik dengan kehidupan nyata [1].

Pengintegrasian budaya lokal ke dalam bahan ajar model inkuiri terbimbing terintegrasi kearifan lokal berbasis OBE penting dilakukan karena pengintegrasian budaya lokal dalam pembelajaran akan mampu mensinergikan antara budaya yang dimiliki oleh peserta didik dan materi-materi yang akan dipelajari sehingga ketika materi disampaikan, peserta didik sudah memiliki pengetahuan awal, 
khususnya tentang budaya lokal yang berkaitan dengan materi yang dipelajari, sebagaimana pendapat [5] menegaskan bahwa keberhasilan proses pembelajaran sains di sekolah sangat dipengaruhi oleh latar belakang budaya yang dimiliki oleh peserta didik atau masyarakat di mana sekolah tersebut berada. Selain itu, hasil proses pembelajaran berbasis OBE mampu mengembangkan kemampuan berfikir peserta didik yang ditandai dengan kemampuan peserta didik mengevaluasi hasil dari pada proses belajarnya, peserta didik mampu memecahkan masalah yang ada di sekitarnya dengan mengintegrasikan nilai-nilai kearifan lokal sebagai upaya dalam melestarikan ekosistem yang ada di lingkungan sekitarnya.

Pendidikan berbasis budaya lokal membuat peserta didik mampu memahami konsep sains yang dipelajari dengan didasarkan pada lingkungan konkret di lingkungan sekitar [7]. Peningkatan literasi sains tidak hanya mengacu pada pemahaman struktur ilmu pengetahuan dan teknologi melainkan juga memahami sifat ilmu pengetahuan dan teknologi dan hubungan mereka dengan lingkungan dan masyarakat [9]. Oleh karena itu, bahan ajar model inkuiri terbimbing terintegrasi kearifan lokal berbasis OBE melalui penggunaan media online mendukung meningkatkan literasi sains peserta didik karena antara sains, lingkungan, teknologi, masyarakat dan tingkat berpikir merupakan salah satu indikator yang ada dalam literasi sains.

\section{KESIMPULAN}

Berdasarkan hasil analisis data dan pembahasan dapat disimpulkan bahwa bahan ajar model inkuiri terbimbing terintegrasi kearifan lokal berbasis outcome based education (OBE) melalui penggunaan media online berpengaruh terhadap literasi sains peserta didik kelas $\mathrm{X}$ di SMAN 8 Mataram.

\section{DATAR PUSTAKA}

[1] Hardianti, F., Setiadi, D., Syukur, A., \& Mertha, I. W. (2021). Pengembangan Bahan Ajar Berbasis Science, Technology, Environment, Society (SETS) Untuk Meningkatkan Literasi Sains Peserta Didik. Jurnal Pijar MIPA, 16 (1), 68-74.

[2] Fidiantara, F., Kusmiyati., \& Mertha, I. W. (2020). Pengaruh Penggunaan Bahan Ajar IPA Materi Sistem Ekskresi Berbasis Inkuiri Terhadap Penigkatan Literasi Sains. Jurnal Pijar MIPA, 15 (1), 88-92.

[3] Jufri, A. W., dan Hikmawati. (2014). Analisis Kemelekan Sains (Scince Literacy) dan Kemelekan Inkuiri (Inquiry Literacy) Guru Mataa Pelajaran IPA SMP. Jurnal Pijar MIPA, 9 (1), 9-14.
[4] Kartono, H., dan Gusti, B. (2010). Penelusuran Budaya dan Teknologi Lokal dalam Rangka Rekonstruksi dan Pengembangan Sains di Sekolah dasar. Pontianak: FKIP Universitas Tanjungpura.

[5] Marheni, N P., dan Suardana, I. N. (2014). Pembelajaran Inkuiri Terbimbing Berbasis Budaya Lokal Pada Pembelajaran Sains Kimia SMP. Jurnal Wahana Matematika dan Sains, 8 (2), 87-100.

[6] Mathew. S. K. (2005). An Investigation Into The Implementation Of Computer-Assisted Education In Outcame Based Education: A Case Study At Sterling Primary School In East London. Thesis. University Of Pretoria.

[7] Montu, F., dan Abjud, T. (2019). Pengembangan Perangkat Pembelajaran Inkuiri Terbimbing Berbasis Budaya Lokal Terhadap Hasil Belajar Pada Materi Energi dalam Sistem Kehidupan. Jambura Physics Journal, 1 (2), 78-88.

[8] Mustofa, M. I., Chodzirin, M., Sayekti, L., \& Fauzan, R. (2019). Formulasi Model Perkuliahan Daring sebagai Upaya Menekan Disparitas Kualitas Perguruan Tinggi. Walisongo Journal of Information Technology, 1 (2), 151-160.

[9] Nugraheni, N. C., Paidi., \& Triatmanto. (2017). Kemampuan Literasi Sains Kelas X SMA Negeri Mata Pelajaran Biologi Berdasarkan Topografi Wilayah Gunung Kidul. Jurnal Prodi Pendidikan Biologi, 6 (5), 261-271.

[10] OECD. (2016). PISA 2015 Result in Focus. Paris: PISA OECD Publishing.

[11] Retnawati, H. (2016). Analisis Kuantitatif Instrumen Penelitian (Panduan Peneliti, Mahasiswa, dan Psikometrian). Yogyakarta: Parama Publishing.

[12] Rohmawati, E. R.,Wahono, W., \& Rudiana, A. (2018). Membangun Kemampuan Literasi Sains Peserta didik Melalui Pembelajaran Berkonteks Socio-Scientific Issues Berbantuan Media. Jurnal Penelitian Pendidikan, 3 (1), 8-14.

[13] Setyaningsih, A., Eko. W., \& Asri, W. (2018). Perbedaan antara Pendekatan Inkuiri Terbimbing dengan Pendekatan Inkuiri Terbimbing Bermuatan Nature of Science pada Pembelajaran IPA terhadap Peningkatan Literasi Sains Peserta Didik SMPN 11 Yogyakarta. Jurnal Pendidikan IPA, 7 (4), 203-208.

[14] Suastra, I. W., dan Luh Putu, B. D. (2013). Model Pembelajaran Fisika Untuk Mengembangkan Kreativitas Berpikir dan Karakter Bangsa Berbasis Kearifan Lokal Bali. Jurnal Pendidikan Indonesia, 2 (2), 221-235.

[15] Sumarti, S., Rahayu, Y. S., \& Madlazim. (2015). Pengembangan Perangkat Pembelajaran Berbasis Inkuiri Terbimbing Untuk Melatih Literasi Sains Siswa. Jurnal Pendidikan Sains Universitas Negeri Surabaya, 5 (1), 822-829. 